\title{
ЗАКОНОДАТЕЛЬНЫЕ МЕРЫ ПРОТИВОСТОЯНИЯ И МИГРАЦИОННАЯ СОСТАВЛЯЮЩАЯ НОВОЙ «МЯГКОЙ УГРОЗЫ» ЕВРОПЕЙСКОМУ СОЮЗУ
}

\begin{abstract}
Аннотация: В статье на основе сравнительно-правового подхода анализируются современные миграционные проиессы и процессы либерализации миграционного законодательства внутри Европейского союза и попытки Брюсселя выстроить защиту своих внешних грании, чтобы противостоять новой «мягкой угрозе» своей безопасности. В статье рассматриваются : европейское законодательство, законодательство отдельных европейских государств в сфере миграционной политики, а также международное првовое регулирование вопросов миграиии. Рассматриваются различные социально-экономические факторы стимулирующие незакнноую миграчию в европеййские государства. Также исследуются отдельные структуры Еврпоейского союза в задачу которых поставлена боьба с незакнной миграџией (ФРОНТЕКС). Констатируется что проведение западными странами «демократических преобразований», привело к наступилению полнейтего хаоса, так как местное население африканских и азиатских государств оказалось поставленным на грань гуманитарной катастрофы. Понятно, что и количество беженцев в Европу возросло многократно. Тем не менее, несмотря на имеющийся негативный опыт подобных вмешательств «с благой целью», Евросоюз продолжает в настоящее время ту же политику в отношении ряда стран, в том числе Украины и Сирии, еще больше усугубляя таким образом «выталкивающий фактор» миграции в этих регионах мира.
\end{abstract}

Ключевые слова: ЕС, бежениы, Дублинская конвенџия, незаконная миграџия, ФРОНТЕКС, мягкая угроза, транзитные страны, реадмиссия, иммиграция, внутриевропейское законодательство.

Abstract: Based on the comparative legal approach, this article analyzes the modern migration processes and the processes of liberalization of migration legislation within the European Union and the Brussel's attempts to build protection of its external boundaries in order to confront the new "soft threat" to its security. The European legislation, legislation of separate European states in the area of migration policy, as well as the international legal regulation on the issues of migration are being reviewed in the course of this research. The author examines various social-economic factors that encourage the illegal migration into the European states, as well as individual structures of the EU responsible for fighting against illegal migration (European Agency for the Management of Operational Cooperation at the External Borders of the Member States of the European Union - Frontex). It is stated that the realization of "democratic reforms" by Western countries lead to the onset of total chaos due to the fact that the local population of African and Asian states found themselves on the edge of the humanitarian disaster. It is evident that the amount of refugees in Europe has grown significantly. However, despite the negative experience of previous policy changes with "good intentions", the EU continues to have the same policy with regards to a number of countries including Ukraine and Syria, further worsening the "push factor" of migration within these regions of the world.

Keywords: European Union, Refugees, Dublin Regulation, Illegal migration, Frontex, Soft threat, Transit countries, Readmission, Immigration, European legislation.

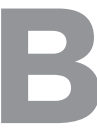

последние годы все больше внимания стало уделяться невоенным составляющим национальной безопасности государств, играющим в своей совокупности достаточно весомую роль в противостоянии специфическим внешним и внутренним угрозам. Эти угрозы, в отличие от жестких военно-политических де- маршей, в настоящее время принято называть «мягкими угрозами», которые возникают в результате различных гуманитарных, экономических, экологических, социальных и других проблем. Одной из таких острых проблем является международная миграция. Миграционные процессы в современном глобальном миропорядке при- 
DOI: $10.7256 / 1811-9018.2015 .10 .13125$

При цитировании этой статьи сноска на dоі обязательна

\section{Право и политика $10(190) \cdot 2015$}

нимают все более масштабные размеры. Пропасть между благополучными и процветающими странами Европы и Северной Америки и находящимися в бедственном положении многочисленными регионами Африки и Азии все увеличивается, а современные средства передвижения и открытость некоторых границ внутри международных союзов (ЕС, СНГ) делают миграцию как все более соблазнительной и все более доступной, так и все более криминальной и приводящей к многочисленным человеческим трагедиям.

Так 3 октября 2013 года информационные агентства сообщили об очередной трагедии у берегов Италии, где недалеко от итальянского острова Лампедуза в Средиземном море потерпел крушение корабль с 500 пассажирами на борту. Из них удалось спасти около 150 человек. Сообщалось, что судно загорелось из-за того, что беженцы разожгли на палубе костер для привлечения внимания. В последнее время тысячи беженцев пытаются добраться по воде до Италии, при этом многие судна терпят крушение. Один из последних случаев произошел 30 сентября прошлого года, когда рядом с одним из пляжей Сицилии были обнаружены тела 13 мигрантов. Беженцы утонули после того, как судно село на мель, а им пришлось добираться до берега вплавь. ${ }^{1}$

За последние годы в несколько раз увеличилось количество жертв людского трафика, пребывающих в Европу транзитом из близлежащих государств. И чем больше либерализировалось миграционное законодательство внутри ЕС, приведя в конечном итоге к ликвидации пограничного контроля на границах между странами - членами союза, тем жестче старался Брюссель выстроить защиту своих внешних границ, чтобы противостоять этой новой «мягкой угрозе» своей безопасности. В частности, за последние 20 лет в ЕС были ужесточены визовые требования, были приняты законодательные меры против перевозчиков незаконных мигрантов, были многократно усилены меры полицейского и военного характера по контролю границ (особенно морских границ Средиземноморья), были подписаны двусторонние межгосударственные соглашения о реадмиссии со многими государствами, граничащими с ЕС или находящимися на пути транзита²

\footnotetext{
${ }^{1}$ У берегов Италии загорелось и затонуло судно с 500 беженцами // URL: http://vz.ru/news/2013/10/3/653235.html (дата обращения 3.10.2013)

2 Директива №2002/90/ЕС «Об установлении определения по помощи незаконному въезду, транзиту и пребыванию» от 28.11.2002 и Рамочное решение Совета 2002/946/ПВД «О повышении стан-
}

Все эти меры усилили экономическую и организационную нагрузку на приграничные и транзитные страны. Сложилась ситуация, которая показывает, что ЕС хочет, чтобы проблемы иммиграции решались за пределами союза, то есть именно в транзитных странах.

Остановимся теперь на характере этих процессов в транзитных странах, входящих в ЕС, и в приграничных по отношению к ЕС государствах. К транзитным странам - членам ЕС, относятся государства, входившие раньше в советский блок (Эстония, Латвия, Литва, Польша, Чехия, Сербия, Венгрия) и присредиземноморские государства - Греция, Италия, Испания, Франция, Кипр, Мальта, но если количество незаконных мигрантов, проникающих в ЕС через ее восточные границы относительно невелико, то поток беженцев и мигрантов из Северной Африки (особенно в связи с последними событиями в этом регионе) становится просто огромным. Эти страны сталкиваются со значительными проблемами, которые создает незаконная миграция, притом, что эти проблемы касаются не только очевидной сферы (социальное напряжение в обществе, рост криминала и т.п.), но и тех обязательств, которые определены для этих стран внутриевропейским законодательством.

В частности, речь идет о Второй Дублинской конвенции 1990 года, которая обязательна для всех стран ЕС. Согласно этой конвенции, лица, стремящиеся получить гражданство или убежище в ЕС, должны обращаться с таким ходатайством в первую же из достигнутых ими «безопасных стран». Все страны ЕС (Австрия, Бельгия, Великобритания, Германия, Греция, Дания, Ирландия, Испания, Италия, Люксембург, Нидерланды, Португалия, Финляндия, Франция, Швеция) в соответствии с этой конвенцией относятся к безопасным странам. Кроме того, вводится еще понятие «третьей безопасной страны», то есть это те страны, которые не входят в ЕС, но которые страны ЕС считают безопасными для беженцев (каждая из стран ЕС вправе сама решать, какие страны она рассматривает как «третьи безопасные»). Принимая такое решение (о высылке в «третью безопасную страну») национальные суды руководствуются сложившейся на данный момент ситуацией. В частности, в 2010 году Миграционный суд в Мальмё (Швеция) приостановил высылку нескольких беженцев из Северной Африки в Грецию (транзитную страну). Таким образом, Миграционный суд Мальме пришел к заключению, что Греция - страна ЕС, являющаяся согласно Дублинской конвенции безопасной

дартов уголовной ответственности в целях наказания за помощь незаконному въезду, транзиту и пребыванию» 
страной, не может гарантировать адекватного с правовой точки зрения процесса рассмотрения ходатайств о предоставлении убежища беженца, подлежащим высылке из Швеции, и постановил, что беженцы должны остаться на территории страны.

Следует отметить, что, уже начиная с 2008 года, шведские миграционные власти не прибегают к депортации в Грецию несовершеннолетних беженцев, у которых отсутствуют родители, считая, что такая высылка может рассматриваться как нарушение международных конвенций по детям ${ }^{3}$.

Фактически суд в Мальмё в одностороннем порядке нарушил Дублинскую конвенция, что вызвало соответствующие комментарии в высшей инстанции с указанием на то, что в настоящее время миграционные суды в Швеции (суд в Мальме, суд в Гетеборге и суд в Стокгольме) не имеют единой точки зрения в отношении того, можно ли рассматривать Грецию, как «безопасную страну» ${ }^{4}$.

С учетом этого и других подобных случаев, в настоящее время концепция «третьей безопасной страны» подвергается значительно критике, в частности, Управление Верховного комиссара $\mathrm{OOH}$ по делам беженцев (УВКБ ООН) полагает, что концепция «третьей безопасной страны» деструктивно подействовала на формирование международного законодательства по защите беженцев. Поэтому данная концепция не является безусловным принципом международного права.

Помимо Дублинской конвенции, документом, peгламентирующим деятельность транзитных государств в отношении мигрантов, находящихся на их территории, является Директива Совета Европейского Союза 2003/9/ЕС от 27 января 2003 года, которая устанавливает стандарты приема лиц, прибывших на территорию ЕС с целью получения права на жительство. В данном документе Совет Европейского Союза установил, в соответствии с Женевской Конвенцией 1951 года и с дополнениями, внесенными в нее Протоколом от 1967 года ${ }^{5}$, принцип невысылки мигрантов, имеющих статус

\footnotetext{
3 Декларация прав ребенка, принятая Генассамблеей ООН в 1959 году. (См. - URL: http://www.un.org/ru/documents/decl_conv/ declarations/childdec.shtml)и Конвенция о правах ребенка, принятая Генассамблеей ООН в 1989 году (См. - URL: http://www. un.org/ru/documents/decl_conv/conventions/childcon.shtml) (дата обращения 07.10.2013)

${ }^{4}$ По информации портала Право.py // URL: http://pravo.ru/ interpravo/news/view/37639/ (дата обращения 07.10.2013)

5 Женевская Конвенция о статусе беженцев принятая 28 июля 1951 года в Женеве конференцией полномочных представителей, созванной в соответствии с резолюцией $429(\mathrm{~V})$ Генеральной Аcсамблеи ООН от 14 декабря 1950 года. Вступила в силу 22 апреля
}

«беженцев», а так же соответствующие стандарты обращения с лицами, ищущими убежище или временно находящимися на территории государства в ожидании определения их статуса.

Другим документом, устанавливающим стандарты действий миграционных властей стран ЕС по отношению к мигрантам, является Директива 2008/115/EC Европейского парламента и Совета от 16 декабря 2008 года об общих стандартах и процедурах, подлежащих применению в государствах-членах к возврату незаконно пребывающих граждан третьих стран.

В своей основе обе Директивы подтверждают основные права и принципы, заложенные Хартией Европейского союза по правам человека ${ }^{6}$. Они гарантируют уважение человеческого достоинства и соблюдение соответствующих норм при обращении с лицами, нуждающимися в убежище, о чем говорится в статье 1 и статье 18 Хартии.

В Директивах даны определения ряда основополагающих терминов «беженец», «статус беженца», «задержание», «заявление о предоставлении убежища», «заявитель», «член семьи», «центр размещения», «условия приема» и другие. Так же разработаны нормы, касающиеся лиц с особым статусом: несовершеннолетние, жертвы пыток и т.п., эти нормы описаны в разделе 4 Директивы 2003/9/ЕС и в Статье 14 Директивы 2008/115/ ЕС. В соответствующих разделах приведены и нормы, касающиеся обжалования действий миграционных властей (Раздел 5 Директивы 2003/9/ЕС и Статья 13 Директивы 2008/115/EC), и направления, касающиеся повышения эффективности системы приема беженцев (раздел 6 Директивы 2003/9/ЕС).

Директивы призваны координировать и стандартизировать национальные законодательства стран ЕС в сфере обеспечения мигрантов приемлемыми условиями пребывания на территории транзитных стран. В документах указывается на необходимость кооперации между государствами - членами ЕС в деятельности по работе с беженцами, в том числе, указывается на необходимость своевременной координации между соответствующими органами, занимающимися приемом, задержанием, размещением и административным

1954 года. 31 января 1967 года Конвенция была дополнена принятым в Нью-Йорке Протоколом, касающимся статуса беженцев// CM. - URL: http://www.un.org/ru/documents/decl_conv/conventions/ refugees.shtml (дата обращения 07.10.2013)

${ }^{6}$ Charter of fundamental rights of the European Union (2000/C 364/01) - Председатели Европейского парламента, совета и комиссия подписали и провозгласили хартию от имени своих учреждений 7 декабря 2000 года в Ницце. 
DOI: $10.7256 / 1811-9018.2015 .10 .13125$

При цитировании этой статьи сноска на dоі обязательна

\section{Право и политика $10(190) \cdot 2015$}

сопровождением лиц, нуждающихся в убежище или в месте временного пребывания, а также стимулированию гармонизации взаимоотношений между местным населением и мигрантами.

Введение минимальных стандартов не означает, что государства не имеют права создавать более благоприятные условия для принятия и размещения беженцев и мигрантов и закреплять эти условия на законодательном уровне. Об этом говорится в статье 4 данной Директивы 2003/9/EC: «Государства-члены могут вводить или сохранять более благоприятные положения в области условий приема для лиц, ищущих убежища».

Во втором разделе Директивы 2003/9/ЕС даны положения, регламентирующие условия приема и административного сопровождения мигранта. Так, не позже, чем через три дня с момента подачи заявления заявитель должен получить документ на свое имя, удостоверяющий его статус, как лица, обратившегося за убежищем. Так же в данном разделе оговаривается право государства, предоставившее мигранту временное убежище, требовать медицинского освидетельствования данного лица ради соблюдения государственных интересов в части охраны здоровья граждан. При этом в разделе 13 Директивы 2003/9/ЕС оговариваются стандарты материальных условий размещения, приема и медицинского обслуживания лиц, просящих убежища. Медицинское обслуживание, согласно пункту 1 статьи 15, должно обеспечивать неотложную медицинскую помощь и лечение в случае острого заболевания.

Материальное обеспечение мигранта должно начинаться с момента подачи им заявления в местные компетентные органы и предоставляться в том объеме, который гарантировал бы данному лицу жизненный уровень, необходимый для сохранения здоровья и существования. Материальное обеспечение может предоставляться как в натуральном виде, так и виде выплаты денежного пособия.

Важно подчеркнуть, что согласно стандартам ЕС в отношении мигрантов, лицо, запросившее убежище, не считается незаконно находящимся на территории страны до тех пор, пока не получит официального отказа в предоставлении права на пребывание в стране - члене ЕС (Статья 2 Директивы 2008/115/ЕС). В случае отказа такое лицо подлежит реадмиссии и должно быть направлено в специальные места содержания (Статья 18 Директивы 2008/115/ЕС): «Центры задержания» или в «Центры для содержания лиц, попадающих под реадмиссию»: «По общему правилу, задержание проводится в специализированных центрах задержания. Когда государство-член ЕС не может поместить граждан третьих стран в специализированный центр задержания, и вынуждено поместить их в пенитенциарное учреждение, эти задержанные граждане содержатся отдельно от обычных заключенных»7. Более того, рекомендуется вообще не использовать тюрьмы для содержания мигрантов, подлежащих высылке, а выделять для этих целей другие помещения, которые не должны иметь сходства с тюрьмами ${ }^{8}$.

В «Центрах задержания» и в «Центрах для содержания лиц, попадающих под реадмиссию», согласно стандартам ЕС должен работать соответствующим образом подготовленный персонал. По стандартам EC, предусмотренных в Директиве (раздел 3), в случае, если мигрант не соблюдает установленные правила (покидает место проживания без надлежащего уведомления, нарушает режим, установленный в местах размещения и т.п.) он может быть ограничен в пользовании услугами. Очевидно, что выполнение всех этих стандартов требует от транзитных государств (а именно на них падает основная нагрузка миграционных потоков) значительных финансовых затрат и административных ресурсов. Когда на периферии ЕС появились новые «молодые» еврогосударства, бывшие члены социалистического лагеря, чья экономика гораздо слабее, чем у лидеров ЕС, начались проблемы и недовольства сложившейся ситуацией, при которой принцип «разделения бремени» стал повсеместно нарушаться.

Помимо вышеназванных мер, направленных в основном на делегирование финансового бремени по решению значительной доли проблем нелегальной миграции странам-транзитерам, руководством ЕС были предприняты и другие действия, в частности с 2005 года в Варшаве (а Польша - это один из основных «транзитеров» нелегальных мигрантов в ЕС) была открыта штаб-квартира ФРОНТЕКС - Агентства по управлению оперативным сотрудничеством на внешних границах государств - членов Европейского Союза9.

В официальном регламенте ЕС (№ 2007/2004) основные функции ФРОНТЕКС обозначены следующим образом:

\footnotetext{
${ }^{7}$ См.: - URL: http://www.consultant.ru/document/cons_doc INT_46209/ (дата обращения 07.10.2013)

${ }^{8}$ Кабинет Министров Совета Европы, Двадцать руководящих принципов принудительного возвращения, 4 мая 2005 года, директива 10.

${ }^{9}$ Frontex (от фр. Frontières extérieures, полное название: European Agency for the Management of Operational Cooperation at the External Borders of the Member States of the European Union)
} 
- Проведение совместных операций-планирование, координация, проведение и оценка результатов операций, проведенных совместно несколькими странами-членами ЕС на внешних границах (морских, наземных и воздушных) Евросоюза.

- Обучение - разработка общих для ЕС стандартов обучения и специализированных учебных программ для пограничных органов в рамках Европейского Союза.

- $\quad$ Анализ рисков - систематический анализ оперативной информации об актуальной ситуации на границах Европейского Союза, ее анализ и прогноз возникновения потенциальных угроз безопасности. Источниками искомой информации являются пограничные пункты, оперативные подразделения пограничных органов стран-членов ЕС и третьих стран, открытые источники информации, СМИ и научные данные.

- Исследования и Развитие - на базе ФРОНТЕКС осуществляется сотрудничество пограничных органов с научными, исследовательскими, промышленными структурами для разработки новейших систем, предназначенных для эффективной охраны границ ЕС.

- Обеспечение быстрого реагирования-ФРОНТЕКС обеспечивает повышенную боеготовность Групп быстрого реагирования (их численный состав превышает 700 человек), а также формирует базы данных о необходимых для их развертывания силах и средствах. Группы быстрого реагирования предназначены для экстренного действия в кризисных ситуациях на границах Евросоюза для ее нейтрализации и предотвращения угрозы безопасности.

- Оказание помочи странам Евросоюза в совместныlх действиях по возвращению иностранных граждан. В случае законного выдворения иностранных граждан, нелегально прибывающих на территорию ЕС, ФРОНТЕКС содействует в проведении депортации, контролируя соблюдение основных прав и свобод по отношению к выдворяемым нелегальным иммигрантам.

- Создание информаиионных системы и обмен информацией. ФРОНТЕКС разрабатывает, эксплуатирует и обеспечивает сохранность информационных систем, предназначенных для сбора, обработки и передачи информации об актуальном состоянии безопасности внешних границ Евросоюза и имеющихся потенциальных угрозах. ФРОНТЕКС не имеет полномочий на проведение оперативно-следственных действий.
Численный состав сотрудников ФРОНТЕКС достигает 300 человек. Это лица, работающие на штатных должностях по контракту (обычно это пятилетние контракты); лица, прикомандированные в качестве национальных экспертов от соответствующих органов стран Евросоюза на различные сроки и административно-технические работники, в основном - польские граждане, поскольку штаб-квартира Агентства находится в Варшаве.

В составе Агентства действуют такие структуры, как Ситуационный иентр, который в режиме онлайн проводит мониторинг средств массовой информации и в других открытых источниках, отслеживает кризисные ситуации. В Центре анализируются полученные из различных источников материалы, относящиеся к вопросам защиты границ. При этом Ситуационный центр функционирует как Центр коммуникации ФРОНТЕКС и отвечает за предоставление доступа к информации Европейского Агентства ${ }^{10}$.

Единый центр ФРОНТЕКС по накоплению и обмену информацией (FOSS) - это информационный портал и Веб-сайт Агентства, где возможно осуществлять аккумуляцию оперативной информацией и обмен ею в рамках Европейского Агентства. B FOSS накапливаются сведения, поступающие от соответствующих структур, осуществляющих охрану морских, воздушных, и сухопутных границ EC, а также структур, занимающихся возвращением граждан третьих стран на родину.

Так же в рамках ФРОНТЕКС действуют целевые проекты, направленные на обеспечение деятельности Агентства.

Единая модель анализа рисков (CIRAM), разработана ФРОНТЕКС в тесном сотрудничестве со странами Евросоюза и используется как на общеевропейском, так и на национальном уровнях для анализа всей поступающей информации о характере и масштабах трансграничной преступности, а так же для координации совместных операций стран Евросоюза, осуществляемых на границах ЕС. При этом, эта модель позволяет осуществлять анализ рисков, исходящих от различного вида угроз ${ }^{11}$.

«Система анализа рисков Восточных границ» (ЕВ$R A N)$, обеспечивающая связь между Отделом анализа рисков Агентства ФРОНТЕКС и аналогичными аналитическими подразделениями пограничных органов России,

\footnotetext{
${ }^{10} \mathrm{http}: / /$ frontex.europa.eu/intelligence/information-management (дата обращения 07.10.2013)

${ }^{11} \mathrm{http}$ ://frontex.europa.eu/intelligence/risk-analysis (дата обращения 07.10.2013)
} 
DOI: $10.7256 / 1811-9018.2015 .10 .13125$

При цитировании этой статьи сноска на dоі обязательна

\section{Право и политика $10(190) \cdot 2015$}

Беларуси, Украины и Молдовы, создана в 2007 году на базе общеевропейского сервера CIRCA для информационного обмена и анализа состояния безопасности на Восточных границах Евросоюза. Другие соседние страны, в особенности государства-участники СНГ, могут быть приглашены для участия в этом проекте ${ }^{12}$. $\mathrm{C}$ системой EB-RAN работают оперативные и аналитические подразделения пограничных органов стран Евросоюза, осуществляя обмен статистикой, аналитикой и другими, относящимися к незаконной миграции. Обмен информацией производится посредством ICONet - Интернет платформы расположенной на сервере Европейской комиссии CIRCA и территориально находящейся в Люксембурге. Помимо «Системы анализа рисков Восточных границ» (EB-RAN), в рамках ФРОНТЕКС совместно с Европейской комиссией на базе сервера CIRCA также была создана информационная платформа «Западные Балканы» для обмена информацией в составе «Системы анализа рисков Западно-Балканских границ».

«Система накопления информации при поведении coвместных операций - (JORA)» - предназначена для управления информационными потоками в ходе проведения совместных мероприятий и сбора данных, необходимых для их проведения. Система создана и модернизируется ФРОНТЕКС и странами-членами ЕС. «JORA» использовалась во всех операциях, проведенных ФРОНТЕКС в 2013 году.

Помимо аналитической работы по обеспечению безопасности границ ЕС (указать протяженность грании) ФРОНТЕКС проводит и полицейские операции по задержанию нелегальных мигрантов на морских и сухопутных границах, а так же в аэропортах. В 2008 году ФРОНТЕКС провел 25 таких операций ${ }^{13}$. На 2013 год запланировано 5 наземных операций, 7 морских и 2 воздушных.

Чтобы представить масштаб проводимых операций приведем для примера установочные данные по некоторым из них.

Наземная операция - Операция «Focal Points 2013 Land» («Центральные пункты на суше 2013»)

Сроки проведения операџии: 1 апреля - 31 декабря 2013 года.

Страны организаторы: Норвегия, Финляндия, Эстония, Литва, Латвия, Польша, Словакия, Словения, Венгрия, Румыния, Болгария, Гречия.

Страны ЕС, приглашаемые к участию: Австрия, Бельгия, Болгария, Швейчария, Чехия, Германия,

\footnotetext{
${ }^{12} \mathrm{http}$ ///frontex.europa.eu/intelligence/strategic-analysis (дата обращения 07.10.2013)

${ }^{13}$ FRONTEX Annual Report, 2008, Annex II.
}

Эстония, Испания, Финляндия, Франция, Италия, Литва, Латвия, Нидерланды, Польша, Португалия, Румылия,, Словения, Словакия.

Участие третьих стран: приглашаются кучастию.

Требуемые силь и средства: 150-200 экспертов различного профиля; 18 автомобилей с приборами ночного видения; 24 патрульных автомобиля, 3 автобуса; 3 детектора по обнаружению работы сердиа.

Требования к кандидатам на участие в операции: возможность перемещения в рамках зоны проведения операции; участие сотрудника в операции не менее 1 месяиа; направление со служебным автотранспортом (для участников из ЕС); участие в брифингах, проводимых мероприятиях и операциях; знание английского языка.

Морская операция - «Негтеs» (Гермес), проводится в иентральной части Средиземного моря.

Цель операции: повышение уровня оперативного взаимодействия в иелях выявления и пресечения потоков нелегальной миграчии, и других преступлений, связанных с пересечением границь со стороны Туниса, Алжсира и Ливии по отношению костровам Лампедуза, Сардиния и Сищилия.

Сроки операщии: июль - сентябрь 2013 года.

Воздушная операция - «Focal Points 2013 Air» («Центральные пункты 2013 по контролю воздушного сообщения»).

Сроки проведения операции: с марта 2013 года по февраль 2014 года.

Цель операции: организация оперативного сотрудничества в целях выявление потоков нелегальной миграичии и других преступлений, связанных с пересечением воздушной границы.

Требования к кандидатам на участие в операции: практический опыт выявления признаков поддельных документов; возможность перемещения в рамках зоны проведения операции; участие в брифингах, проводимых мероприятиях и операциях; знание английского языка.

Участие третьих стран: приглашаются кучастию ${ }^{14}$.

Но какие бы усилия не прикладывались к защите границ Евросоюза от наплыва нелегальных иммигрантов, очевидно, что решение проблемы лежит в другой плоскости, а именно в плоскости тех факторов, которые стимулируют подобные массовые миграционные потоки. Причины, побуждающие людей к бегству из своей страны и незаконному пересечению чужих границ, принято называть «выталкивающими факторами». Это

\footnotetext{
${ }^{14}$ По материалам сайта Совета командующих пограничными войсками CHГ // URL: http://www.skpw.ru/ (дата обращения 02.10.2013)
} 
военные и социальные конфликты, природные катастрофы, нищета, политическая нестабильность и т.п. К «выталкивающим факторам» можно так же отнести и деятельность организованных преступных групп масштабно занимающихся трафиком «живого товара», которые заинтересованы в расширении своего бизнеса и порою склоняют к выезду из страны людей, до этого не имевших намерения эмигрировать.

Наряду с «выталкивающими факторами» наличествуют и «притягивающие факторы», формирующиеся внутри страны реципиента. Понятно, что основным таким «притягивающим фактором» является постоянный спрос на дешевую рабочую силу. Но притягательностью обладает, разумеется, и само по себе высокое качество жизни в Евросоюзе. ЕС прилагает большие усилия к тому, чтобы противостоять этой новой «мягкой угрозе» - массовой нелегальной иммиграции - совершенствуя внутреннее законодательство и заключая соглашения, регулирующие миграционные процессы, со странами исхода и со странами транзита. Особенно эффективной в последнее время является деятельность стран ЕС по ликвидации некоторых «притягивающих факторов»: введение уголовной ответственности за использование труда нелегальных иммигрантов; меры, направленные против фиктивных браков; защита прав жертв «торговли людьми» и т.п.
В то же время в том, что касается «выталкивающих факторов», то в последнее время страны ЕС в этом отношении больше способствуют их нарастанию, чем сокращению. Речь идет о событиях последних лет в Северной Африке и на Ближнем Востоке, которые традиционно были поставщиками большого количества беженцев в Европу, но после войны в Ираке и Афганистане (в которой участвовали военные контингенты стран ЕС), после поддержанных Европой цветных революций в Египте и Тунисе, после свержения при поддержке стран НАТО режима Каддафи в Ливии, «выталкивающий фактор» в этом регионе стал приобретать уже катастрофический характер, поскольку во всех тех странах, где Запад вообще и Европа в частности пытались провести «демократические преобразования», наступил полнейший хаос, и местное население оказалось поставленным на грань гуманитарной катастрофы. Понятно, что и количество беженцев в Европу возросло многократно. Тем не менее, несмотря на имеющийся негативный опыт подобных вмешательств «с благой целью», Евросоюз продолжает в настоящее время ту же политику в отношении ряда стран, в том числе и Сирии, еще больше усугубляя таким образом «выталкивающий фактор» в этом регионе мира. А насколько это будет угрожать безопасности Европы в долгосрочной перспективе, скорее всего, покажет время.

\section{Библиография:}

1. Директива №2002/90/ЕС «Об установлении определения по помощи незаконному въезду, транзиту и пребыванию» от 28.11.2002.

2. Рамочное решение Совета Европы 2002/946/ПВД «О повышении стандартов уголовной ответственности в целях наказания за помощь незаконному въезду, транзиту и пребыванию».

3. Декларация прав ребенка, принятая Генассамблеей ООН в 1959 году. (См. - URL: http://www.un.org/ru/documents/decl_conv/ declarations/childdec.shtml) (дата обращения 07.07.2014)

4. Конвенция о правах ребенка, принятая Генассамблеей ООН в 1989 году (См. - URL: http://www.un.org/ru/documents/ decl_conv/conventions/childcon.shtml) (дата обращения 03.07.2014)

5. Charter of fundamental rights of the European Union (2000/C 364/01)

6. А. Ю. Ястребова Международно-правовое регулирование миграции: эволюция, основы, иммиграционные приоритеты Российской Федерации и стран Европейского союза // Международное право и международные организации / International Law and International Organizations. - 2012. - 1. - C. 91-99.

7. И.В. Сурма, Г.В. Терентьева Нормативно-правовые документы, составляющие законодательную основу миграционной политики ЕС на примере Италии // Политика и Общество. - 2013. - 3. - C. 358-367. DOI: 10.7256/1812-8696.2013.03.13.

8. И.В. Сурма Актуальные вопросы правового регулирования транзитной миграции // Журнал зарубежного законодательства и сравнительного правоведения. - 2012. - 1. - С. 127-131.

9. В. А. Волох Миграционная политика: концептуальный подход // Политика и Общество. - 2012. - 4. - С. 131-136.

10. Волох В.А. Миграционная политика: реадмиссия - эффективный инструмент противодействия нелегальной миграции // NB: Национальная безопасность. - 2012. - 1. - C. 255-270. URL: http://www.e-notabene.ru/nb/article_106.html

11. Семченков А.С.. Современные сценарии политической дестабилизации России // Международные отношения. - 2013. № 3. - С. 345-352. DOI: 10.7256/2305-560Х.2013.3.8816

12. Адмиралова И.А., Гришин Ю.Н.. К вопросу о соответствии законодательства стран ОДКБ, регулирующего борьбу с торговлей людьми международным актам // Полицейская деятельность. - 2013. - № 3. - C. 211-212. DOI: 10.7256/2222-1964.2013.3.9050.

13. Смирнова Е.С.. Проблемы демографической и этнокультурной безопасности в условиях высокого уровня миграции: мировой опыт // Политика и Общество. - 2013. - № 6. - С. 687-701. DOI: 10.7256/1812-8696.2013.6.8602. 
DOI: $10.7256 / 1811-9018.2015 .10 .13125$

При цитировании этой статьи сноска на dоі обязательна

\section{Право и политика $10(190) \cdot 2015$}

14. Черняк А.В.. Приоритетные направления миграционного сотрудничества России и ЕС // Политика и Общество. - 2013. - № 6. - C. 739-745. DOI: 10.7256/1812-8696.2013.6.8112.

15. В.В Бубликов. Исламизация Европы как следствие дехристианизации и демографического кризиса // Тренды и управление. - 2013. - № 2. - С. 156-164. DOI: 10.7256/2307-9118.2013.2.5328.

16. Терентьева Г. В.. Новый Глобальный подход ЕС к миграции и мобильности (GAMM) и социальные аспекты миграционной политики Италии // Тренды и управление. - 2013. - № 3. - C. 62-71. DOI: 10.7256/2307-9118.2013.3.6592.

17. Игонин Д.И.. Определение стратегических приоритетов в государственной миграционной политике России как превентивная мера социальной дезадаптации. // Тренды и управление. - 2013. - № 4. - C. 41-57. DOI: 10.7256/2307-9118.2013.4.4880.

18. Ахатов Ю.К.. Перспективные направления совершенствования социального управления процессами трудовой миграцией в Сахалинской области // Национальная безопасность / nota bene. - 2013. - № 6. - C. 4-10. DOI: 10.7256/2073-8560.2013.6.10538.

19. Андреев М.В.. Стратегии развития межкультурного диалога в контексте укрепления национальной безопасности: актуальные проблемы общественно-политической доктрины Западной Европы и США // Национальная безопасность / nota bene. - 2013. - № 6. - С. 35-45. DOI: 10.7256/2073-8560.2013.6.10657.

20. Г.В. Терентьева. Новый Глобальный подход ЕС к миграции и мобильности (GAMM) и социальные аспекты миграционной политики Италии // Политика и Общество. - 2013. - № 4. - С. 472-478. DOI: 10.7256/1812-8696.2013.04.12.

21. Ю.К. Ахатов. Социологические подходы к анализу миграционной политики // Тренды и управление. - 2013. - № 1. С. 41-48. DOI: 10.7256/2307-9118.2013.01.5.

22. И.В. Сурма, Г.В. Терентьева. Нормативно-правовые документы, составляющие законодательную основу миграционной политики ЕС на примере Италии // Политика и Общество. - 2013. - № 3. - C. 358-367. DOI: 10.7256/1812-8696.2013.03.13.

23. Е.С. Смирнова. Опасность ухудшения криминогенной обстановки в связи с ростом незаконной миграции: мировой опыт // Политика и Общество. - 2012. - № 10. - С. 49-65.

24. В.А. Волох. Миграционная политика: реадмиссия - эффективный инструмент противодействия нелегальной миграции // Национальная безопасность / nota bene. - 2012. - № 5. - C. 96-102

25. А. Ю. Ястребова Международно-правовое регулирование миграции: эволюция, основы, иммиграционные приоритеты Российской Федерации и стран Европейского союза // Международное право и международные организации / International Law and International Organizations. - 2012. - 1. - C. $91-99$.

26. Волох В.А. Миграционная политика: реадмиссия - эффективный инструмент противодействия нелегальной миграции // NB: Национальная безопасность. - 2012. - 1. - С. 255 - 270. URL: http://www.e-notabene.ru/nb/article_106.html

27. Волох В.А. Трудовая миграция: законодательство и политика // NB: Вопросы права и политики. - 2013. - 3. - C. 1 - 20. DOI: 10.7256/2305-9699.2013.3.594. URL: http://www.e-notabene.ru/lr/article_594.html

28. Некрасов А.И. Основы правового регулирования политики Европейского Союза в области финансовых услуг // Международное право и международные организации / International Law and International Organizations. - 2013. - 2. C. 210 - 209. DOI: 10.7256/2226-6305.2013.2.6341.

29. В. А. Волох Миграционная политика: концептуальный подход // Политика и Общество. - 2012. - 4. - С. 131 - 136.

\section{References (transliterated):}

1. A. Yu. Yastrebova Mezhdunarodno-pravovoe regulirovanie migratsii: evolyutsiya, osnovy, immigratsionnye prioritety Rossiiskoi Federatsii i stran Evropeiskogo soyuza// Mezhdunarodnoe pravo i mezhdunarodnye organizatsii / International Law and International Organizations. - 2012. - 1. - C. 91-99.

2. 7. I.V. Surma, G.V. Terent'eva Normativno-pravovye dokumenty, sostavlyayushchie zakonodatel'nuyu osnovu migratsionnoi politiki ES na primere Italii // Politika i Obshchestvo. - 2013. - 3. - C. 358-367. DOI: 10.7256/1812-8696.2013.03.13.

3. I.V. Surma Aktual'nye voprosy pravovogo regulirovaniya tranzitnoi migratsii // Zhurnal zarubezhnogo zakonodatel'stva i sravnitel'nogo pravovedeniya. - 2012. - 1. - C. 127-131.

4. V. A. Volokh Migratsionnaya politika: kontseptual'nyi podkhod // Politika i Obshchestvo. - 2012. - 4. - C. 131-136.

5. Volokh V.A. Migratsionnaya politika: readmissiya - effektivnyi instrument protivodeistviya nelegal'noi migratsii // NB: Natsional'naya bezopasnost'. - 2012. - 1. - C. 255-270. URL: http://www.e-notabene.ru/nb/article_106.html

6. Semchenkov A.S.. Sovremennye stsenarii politicheskoi destabilizatsii Rossii // Mezhdunarodnye otnosheniya. - 2013. - № 3. S. 345-352. DOI: 10.7256/2305-560X.2013.3.8816

7. Admiralova I.A., Grishin Yu.N.. K voprosu o sootvetstvii zakonodatel'stva stran ODKB, reguliruyushchego bor'bu s torgovlei lyud'mi mezhdunarodnym aktam // Politseiskaya deyatel'nost'. - 2013. - № 3. - S. 211-212. DOI: 10.7256/2222-1964.2013.3.9050.

8. Smirnova E.S.. Problemy demograficheskoi i etnokul'turnoi bezopasnosti v usloviyakh vysokogo urovnya migratsii: mirovoi opyt // Politika i Obshchestvo. - 2013. - № 6. - S. 687-701. DOI: 10.7256/1812-8696.2013.6.8602.

9. Chernyak A.V.. Prioritetnye napravleniya migratsionnogo sotrudnichestva Rossii i ES // Politika i Obshchestvo. - 2013. - № 6. S. 739-745. DOI: 10.7256/1812-8696.2013.6.8112.

10. V.V Bublikov. Islamizatsiya Evropy kak sledstvie dekhristianizatsii i demograficheskogo krizisa // Trendy i upravlenie. - 2013. - № 2. - S. 156-164. DOI: 10.7256/2307-9118.2013.2.5328.

11. Terent'eva G. V.. Novyi Global'nyi podkhod ES k migratsii i mobil'nosti (GAMM) i sotsial'nye aspekty migratsionnoi politiki Italii // Trendy i upravlenie. - 2013. - № 3. - S. 62-71. DOI: 10.7256/2307-9118.2013.3.6592. 
DOI: $10.7256 / 1811-9018.2015 .10 .13125$

При цитировании этой статьи сноска на ооі обязательна

Международные отношения: системы взаимодействия

12. Igonin D.I.. Opredelenie strategicheskikh prioritetov v gosudarstvennoi migratsionnoi politike Rossii kak preventivnaya mera sotsial'noi dezadaptatsii. // Trendy i upravlenie. - 2013. - № 4. - S. 41-57. DOI: 10.7256/2307-9118.2013.4.4880.

13. Akhatov Yu.K.. Perspektivnye napravleniya sovershenstvovaniya sotsial'nogo upravleniya protsessami trudovoi migratsiei $\mathrm{v}$ Sakhalinskoi oblasti // Natsional'naya bezopasnost' / nota bene. - 2013. - № 6. - S. 4-10. DOI: 10.7256/2073-8560.2013.6.10538.

14. Andreev M.V.. Strategii razvitiya mezhkul'turnogo dialoga v kontekste ukrepleniya natsional'noi bezopasnosti: aktual'nye problemy obshchestvenno-politicheskoi doktriny Zapadnoi Evropy i SShA // Natsional'naya bezopasnost' / nota bene. - 2013. - № 6. - S. 35-45. DOI: 10.7256/2073-8560.2013.6.10657.

15. G.V. Terent'eva. Novyi Global'nyi podkhod ES k migratsii i mobil'nosti (GAMM) i sotsial'nye aspekty migratsionnoi politiki Italii // Politika i Obshchestvo. - 2013. - № 4. - S. 472-478. DOI: 10.7256/1812-8696.2013.04.12.

16. Yu.K. Akhatov. Sotsiologicheskie podkhody k analizu migratsionnoi politiki // Trendy i upravlenie. - 2013. - № 1. - S. 41-48. DOI: $10.7256 / 2307-9118.2013 .01 .5$.

17. I.V. Surma, G.V. Terent'eva. Normativno-pravovye dokumenty, sostavlyayushchie zakonodatel'nuyu osnovu migratsionnoi politiki ES na primere Italii // Politika i Obshchestvo. - 2013. - № 3. - S. 358-367. DOI: 10.7256/1812-8696.2013.03.13.

18. E.S. Smirnova. Opasnost' ukhudsheniya kriminogennoi obstanovki v svyazi s rostom nezakonnoi migratsii: mirovoi opyt // Politika i Obshchestvo. - 2012. - № 10. - S. 49-65.

19. V.A. Volokh. Migratsionnaya politika: readmissiya - effektivnyi instrument protivodeistviya nelegal'noi migratsii // Natsional'naya bezopasnost' / nota bene. - 2012. - № 5. - S. 96-102

20. A. Yu. Yastrebova Mezhdunarodno-pravovoe regulirovanie migratsii: evolyutsiya, osnovy, immigratsionnye prioritety Rossiiskoi Federatsii i stran Evropeiskogo soyuza // Mezhdunarodnoe pravo i mezhdunarodnye organizatsii / International Law and International Organizations. - 2012. - 1. - C. $91-99$.

21. Volokh V.A. Migratsionnaya politika: readmissiya - effektivnyi instrument protivodeistviya nelegal'noi migratsii // NB: Natsional'naya bezopasnost'. - 2012. - 1. - C. 255 - 270. URL: http://www.e-notabene.ru/nb/article_106.html

22. Volokh V.A. Trudovaya migratsiya: zakonodatel'stvo i politika // NB: Voprosy prava i politiki. - 2013. - 3. - C. 1 - 20. DOI: 10.7256/2305-9699.2013.3.594. URL: http://www.e-notabene.ru/lr/article_594.html

23. Nekrasov A.I. Osnovy pravovogo regulirovaniya politiki Evropeiskogo Soyuza v oblasti finansovykh uslug // Mezhdunarodnoe pravo i mezhdunarodnye organizatsii / International Law and International Organizations. - 2013. - 2. - C. 210 - 209. DOI: 10.7256/2226-6305.2013.2.6341.

24. V. A. Volokh Migratsionnaya politika: kontseptual'nyi podkhod // Politika i Obshchestvo. - 2012. - 4. - C. 131 - 136. 